NOTE

\title{
RELIGIOUS PREFERENCES IN EMPLOYMENT DECISIONS: HOW FAR MAY RELIGIOUS ORGANIZATIONS GO?
}

\section{INTRODUCTION}

When religious organizations assert that their religious mission mandates faitli-based preferences in employment decisions, the Civil Riglits Act's prohibition against religious discrimination ${ }^{1}$ inevitably claslies witli the requirements of the first amendınent's religion clauses. Title VII inakes it unlawful for employers to discriminate witl respect to liring, discharge, coinpensation, terms, conditions, or privileges of einployinent, because of an individual's race, color, religion, sex, or national origin. ${ }^{2}$ This statute has been interpreted as an attempt by Congress to "eliminate all forms of unjustified discrimination in employment."3 In contrast, the United States Supreme Court lias lield that the religion clauses cominand "tliat governinent neitlier engage in nor coinpel religious practices, thiat it effect no favoritism among sects or between religion and nonreligion, and that it work deterrence of no religious belief." 4 To alleviate the tension between the religion clauses and Title VII, Congress enacted a special exeinption froin Title VII for religious organizations. 5 This exeinption, set fortli in section 702 of the Act, allows religious organizations to exercise religious preferences when making employinent decisions. ${ }^{6}$

The breadth of the riglit to discriminate granted to religious organizations by section 702 led to claims that this provision conflicts witli tle religion clauses' requirement that governinent not show favoritism toward religion. ${ }^{7}$ However, in Corporation of Presiding Bishop v. Amos, the Supreme Court upheld the constitutionality of the section 702 exemption

1. Title VII of the Civil Rights Act of 1964, $\S 703,42$ U.S.C. $\S 2000 \mathrm{e}-2$ (1988).

2. Id. $\S 2000 \mathrm{e}-2(\mathrm{a})(1)$.

3. Feldstein v. Christian Science Monitor, 555 F. Supp. 974, 976 (D. Mass. 1983).

4. School Dist. v. Schempp, 374 U.S. 203, 305 (1963) (Goldberg, J., concurring).

5. Feldstein, 555 F. Supp. at 976.

6. 42 U.S.C. $\$ 2000$ e-1 (1988) [hereinafter section 702].

7. See infra notes $52-65$ and accompanying text. 
as applied to both the religious and secular activities of religious organizations. ${ }^{8}$ Despite the holding in Amos, ambiguities concerning the scope of the exemption remain. Uncertainties arise both because the Court left certain questions unaddressed in Amos and because of section 702's vagueness. This Note assesses the current state of section 702 and develops a framework for determining what kinds of activities and what areas of the employment relationship the exemption should cover.

Part I outlines the requirements of the free exercise clause and the establishment clause of the first amendinent and exainines the tensions that arise between them. This Part then summarizes the history of the section 702 exemption and the types of preferences courts have allowed under its provisions. Part II examines the activities of religious organizations that are currently covered by the exemption and makes recoinmendations concerning the scope of the exemption. This Part first addresses the Supreme Court's decision in $A m o s,{ }^{9}$ which held that section 702 covers secular activities of religious organizations. Inquiring into whether the Amos analysis should apply to both nonprofit and for-profit secular activities, or whether the coverage of for-profits should extend only to those activities that are religious in nature, this Part takes the position that the religion clauses require that the exemption extend only to those for-profit activities that are religious in nature.

Part III seeks to determine what aspects of the employinent relationship the exemption covers. It begins by examining possible definitions of the term "employment" in section 702 and compares these possibilities with the Equal Employment Opportunity Coinunission (EEOC) definition of the term. This Part then analyzes hiring and discharge decisions to discern whether such decisions would be covered under the EEOC's interpretation of the term "employment." This Section further discusses the EEOC's position on whether the term "einployment" in section 702 covers terms, conditions, and privileges of employment and also examines the ramifications of its position for the religious employer's right to discriminate with regard to coinpensation, insurance and like benefits, and promotions. In conjunction with this analysis, Part III also offers an alternative analysis of the different components of the employment relationship. This Part recominends looking at terms, conditions, and privileges individually to determine whether extending the exemption to cover that aspect of employment coincides with the purpose of section 702 and the requirements of the religion clauses. Using this approach, this Part concludes that promotion opportunities

8. 483 U.S. 327 (1987). For further discussion of $A m o s$, see infra notes $66-84$ and accompanying text.

9. 483 U.S. at 327 . , 
should be included within the exemption, while opportunities for compensation and insurance and like benefits should not.

\section{The Requirements of the Religion Clauses and the ENACTMENT OF SECTION 702}

\section{A. Requirements of the Religion Clauses}

The first amendment to the United States Constitution seeks to protect religious freedom through two separate clauses. The establishment clause provides that "Congress shall make no law respecting an establishment of religion." 10 The free exercise clause requires that Congress enact no laws "prohibiting the free exercise" of religion." These two mandates comprise the religion clauses.

In Lemon v. Kurtzman, the Supreme Court formulated a test to determme whether government action satisfies the prohibition set forth in the establishment clause. ${ }^{12}$ Lemon involved a challenge to state statutes that granted aid to religious schools which complied with various restrictions. ${ }^{13}$ The plaintiffs alleged that by granting aid to religious schools, the statute constituted an establishment of religion by the government in violation of the first amendment. The Court announced a three-part test to analyze whether a statute violates the establishment clause. The first prong of the test requires that the statute have a "secular legislative purpose." 14 The Court in Amos held that this requirement does not mean that the purpose of the law must be unrelated to religion - that would require an indifference to religious groups never before read into the establishment clause. ${ }^{15}$ The establishment clause does not excuse the government from recognizing those situations in which it must accommodate religious practices-it does not give the government leave to violate the free exercise clause. ${ }^{16}$ Instead, according to Amos, this requirement is designed to prevent the government "from abandoning neutrality and acting with the intent of promoting a particular point of view in religious matters." 17

10. U.S. CONST. amend. I.

11. Id.

12. 403 U.S. $602,612-13$ (1971).

13. These restrictions included strict record-keeping requirements so that the states could ensure that there was no reimbursement for courses involving the teaching of religion. Id. at 607-10.

14. Id. at 612.

15. Corporation of Presiding Bishop v. Amos, 483 U.S. 327, 334 (1987) (citing Zorach v. Clauson, 343 U.S. 306,314 (1952)).

16. See infra notes 20-25 and accompanying text. See also Hobbie v. Unemployment Appeals Comm'n, 480 U.S. 136, 144-45 (1987).

17. 483 U.S. at 335 . 
The second part of the Lemon test requires that the statute in question have "a principal or primary effect ... that neither advances nor inhibits religion."18 The goal of this requirement is not to prohibit laws that merely allow churches to advance religion. ${ }^{19}$ Rather, according to Amos, a violation of this prong of the Lemon test occurs if "the government itself has advanced religion through its own activities and influence."20

The third prong of the Lemon test requires that the law not "foster an excessive government entanglement with religion." 21 To determine whether a given statute violates this requirement, a court must examine three factors, "the character and purpose of the institutions that are benefited, the nature of the aid that the State provides, and the resulting relationship between the government and the religious authority."22

The requirements of the establishment clause as interpreted in Lemon impose a strict limit on the extent to which government may accommodate religion. In contrast, the free exercise clause requires that government accommodate the religious beliefs of private citizens. The Supreme Court has interpreted the free exercise clause to "withdraw[ ] from legislative power, state and federal, the exertion of a restraint on the free exercise of religion. Its purpose is to secure the religious liberty of the individual by prohibiting any invasions thereof by civil authorities."23 To determine whether a statute, such as Title VII, violates the free exercise clause, courts typically engage in a three-part analysis ${ }^{24}$-an analysis that bears a similarity to the establishment clause inquiry. The free exercise inquiry involves tliree factors: (1) the magnitude of the statute's impact on the exercise of a religious belief; (2) the existence of a compelling state interest that justifies the burden imposed upon the exercise of the religious belief; and (3) the extent to which recognition of an exemption from the statute would impede the statutory objectives. ${ }^{25}$ Given that "much of religious life is inherently associational,"26 the free exercise rights granted to private citizens extend to religious organizations as well. ${ }^{27}$ Because of the communal nature of religion, many individuals

18. Lemon, 403 U.S. at 612.

19. Amos, 483 U.S. at 337.

20. Id.

21. Lemon, 403 U.S. at 613 (quoting Walz v. Tax Comm'n, 397 U.S. 664,674 (1970)).

22. Id. at 615 .

23. School Dist. v. Schempp, 374 U.S. 203, 222-23 (1963).

24. EEOC v. Pacific Press Publishing Ass'n, 676 F.2d 1272, 1279 (9th Cir. 1982) (citations omitted).

25. Id.

26. L. TRibe, American Constitutional LAW $\S 14-1$, at 1155 (1988).

27. Id. 
practice their religion through organizations formed to bring together those with similar beliefs. ${ }^{28}$ If individuals are to fully exercise their religious rights, then these organizations also must have free exercise protections. ${ }^{29}$

Government creates a three-way web of tensions when it attempts to legislate in areas that concern employment in religious organizations. First, the free exercise clause requires that government action not force employees to abandon tlieir religious beliefs to attain employment. ${ }^{30} \mathrm{Sec}-$ ond, the government should not intrude on the free exercise right of a rehigious institution to select employees who will best carry out its religious mission. ${ }^{31}$ Third, the establishment clause mandates tliat governmental action must not constitute an establishment of religion. ${ }^{32}$ The Court, however, has recognized that government may-and sometimes must-accommodate religious beliefs under the establishment clause. ${ }^{33}$ The application of Title VII's proscription of religious discrimination to religious organizations creates such a three-way tension.

28. Laycock, Towards a General Theory of the Religion Clauses: The Case of Church Labor Relations and the Right to Church Autonomy, 81 CoLUM. L. REv. 1373, 1389 (1981).

29. Id. See also Corporation of Presiding Bishop v. Amos, 483 U.S. 327, 342-43 (1987) (Brennan, J., concurring in judgment) ("furtherance of the autonomy of religious organizations often furthers individual religion's freedom as well").

30. This right is codified in Title VII's prohibition of religious discrimination, 42 U.S.C. $\$ 2000 \mathrm{e}-2$ (a)(1) (1988), and is inherent in the protections of the first amendment's free exercise clause. See Sherbert v. Verner, 374 U.S. 398, 403-04 (1963) (state's refusal to pay unemployment compensation to an employee fired for unwillingness to work on Saturdays, her religion's day of rest, held to place "the same kind of burden upon the free exercise of religion as would a fine imposed against [her] for her Saturday worship"); Thomas v. Review Bd. Ind. Employment Sec. Div., 450 U.S. 707, 716-18 (1981) (Court found employee was unfairly denied unemployment benefits since he was "put to a choice between fidelity to religious belief or cessation of work" when he was forced to resign or work on the production of weapons); see also Amos, 483 U.S. at 342 (Brennan, J., concurring in judgment) (by enacting seetion 702 and allowing religious organizations to exercise religious preferences in employment, government infringes on free exercise rights "since a religious organization is able to condition employment in certain activities on subscription to particular religious tenets.").

31. Amos, 483 U.S. at 342 (Brennan, J., concurring in judgment) (frec exercise requires that religious organizations have the ability to determine activities that are in furtherance of the religious mission of the organization and to require that only those committed to that mission should carry them out). For further discussion of this rationale, see infra notes 128-30 and accompanying text.

32. See, e.g., Thornton v. Caldor, Inc., 472 U.S. 703 (1985) (Court held state statute requiring employers to give every worker a day off on her day of Sabbath observance violated the establishment clause).

33. Hobbie v. Unemployment Appeals Comm'n, 480 U.S. 136, $144-45$ (requiring state to pay unemployment compensation to employee who chose to quit her position rather than work on Saturday, her day of worship). 


\section{B. Enactment (and Amendment) of Section 702}

Section 702 was enacted in response to concerns over the power of Congress to regulate the employment practices of religious organizations. ${ }^{34}$ Without some exemption for religious organizations, Title VII's proscription of discrinination on the basis of religion could hinder the free exercise right of religious organizations to choose only inembers of their own religion to carry out their religious mission. The denial of this right would inhibit rehgious activity and entangle the government in religious affairs. However, any exemption from Title VII's ban on religious discrimination would imfringe on the right of employees and prospective employees to exercise their rehgious beliefs without suffering foreclosure of employinent opportunities. Further, an exemption which went beyond allowing preferences in positions related to the religious mission of the organization could violate the establishment clause by favoring religious organizations. In response to these concerns, section 702 , in its original form, allowed religious organizations to exercise religious preferences only in employment decisions that affected their religious activities. $^{35}$ However, in 1972, a congressional amendinent eliminated this qualification and allowed religious preference to play a role in all of a rehigious organization's activities. ${ }^{36}$ The enactment and amendnient of section 702 imdicates that-at least with regard to some aspects of the einployment relationship-Congress has determined that the free exercise rights of the rehigious organization outweigh the free exercise rights of the einployee.

Although section 702 clarified certain issues, it did not remove all of the ambiguities involved in determining how to balance the protections of the religion clauses when assessing the employinent decisions of religious organizations. Few of the remaining uncertainties have been clarified by subsequent judicial decisions. One area that has been clarified concerns the extent to which a religious organization's free exercise

34. Feldstein v. Christian Science Monitor, 555 F. Supp. 974, 976 (D. Mass. 1983).

35. This section originally provided that:

This title shall not apply to ... a religious corporation, association, or society with respect to the employment of individuals of a particular religion to perform work connected with the carrying on by such corporation, association, or society of its religious activities or to an educational institution with respect to the employment of individuals to perform work connected with the educational activities of such institution.

Title VII of the Civil Rights Act of 1964, Pub. L. No. 88-352, $§ 702,78$ Stat. 241, 255 (1964), amended by Pub. L. No. 92-261, 86 Stat. 103 (1972) (emphasis added).

36. The current exemption provides that the prohibition against religious discrimination "shall not apply ... to a religious corporation, association, educational institution, or society with respect to the employment of individuals of a particular religion to perform work connected with the carrying on by such corporation, association, educational institution, or society of its activities." Equal Employment Opportunity Act of 1972, 42 U.S.C. § 2000e-1 (1988). 
rights allow it to select individuals on the basis of sex, race, and other criteria forbidden by Title VII. The courts have answered this question in different ways depending on whether the employment decision involves pastoral staff or other types of employees. With regard to employment decisions that involve pastoral staff, the courts have held that the religion clauses' protections require a complete exemption from Title VII's restrictions. ${ }^{37}$ In this situation, the right of the religious organization to freely exercise its religion by choosing who will carry out the primary task of furthering its religious mission outweighs the employee's right under Title VII to be free from discrimination in employment.

With regard to non-pastoral positions, both the courts and the EEOC have reached the opposite conclusion when considering discrimination on bases other than religion. Outside the pastoral context, the right of the religion to be free from government interference has not been viewed as compelling enough to offset the individual's right to be free from discrimination based on race, sex, color, national origin, ${ }^{38}$ or age. ${ }^{39}$ According to caselaw, however, employers may overcome Title VII's prohibition by presenting convincing evidence that the challenged employment practice is based on religious grounds. ${ }^{40}$ Once the organization meets this burden, the EEOC lacks jurisdiction to conduct further investigation into whether the religious discrimination was merely a pretext for another form of discrimination. ${ }^{41}$

The cases interpreting section 702 help clarify both the bases upon which religious organizations may discriminate and how this determination varies according to the employment position involved. ${ }^{42}$ The language of the exemption provision also demonstrates that discrimination

37. McClure v. Salvation Army, 460 F.2d 553 (5th Cir.), cert. denied, 409 U.S. 896 (1972). In McClure, the Fifth Circuit upheld the district court's dismissal of a complaint by a Salvation Army minister who charged that the Salvation Army discriminated on the basis of sex, thus violating Title VII. Since consideration of matters involving the church-pastor relationship would involve the state in the internal affairs of religion, the court found that all aspects of this relationship were exempt. Id. at 560-61. See also Rayburn v. General Conference of Seventh-day Adventists, 772 F.2d 1164 (4th Cir. 1985) (claim of sex discrimination in hiring not successful since plaintiff was seeking a pastoral position), cert. denied, 478 U.S. 1020 (1986).

38. See Rayburn, 772 F.2d at 1168 (maintaining that section 702 does not apply to sex discrimination by religious organizations except as regards pastoral positions); EEOC v. Pacific Press Publishing Ass'n, 676 F.2d 1272, 1276 (9th Cir. 1982) (in response to sex discrimination claim court held that "religious employers are not immune from liability for discrimination based on race, sex, national origin").

39. Religious Organization Exemption, EEOC Compliance Manual (CCH) If 2183, at 2365.

40. See EEOC v. Mississippi College, 626 F.2d 477, 485 (5th Cir. 1980), cert. denied, 453 U.S. 912 (1981). In Mississippi College a female professor challenged the college's practice of hiring only males to teach Bible courses. The court found that in this case Title VII would not be violated by allowing the EEOC to investigate.

41. Id.

42. See supra notes $34-41$ and accompanying text. 
on the basis of religion is permissible in at least part of the employment relationship. The remaimder of this Note addresses the application of section 702; in particular, it addresses two questions, the answers to which remain unclear.

One area of ambiguity concerns the kinds of activities in which religious organizations may exercise preferences. Initially, it was not clear whether the statute applied to both secular and religious activities. Althougli the Supreme Court ruled that the exemption constitutionally can apply to all secular and religious activities of religious organizations, ${ }^{43}$ it is not clear whether section 702 also should apply to for-profit activities. Anotler ambiguity in the interpretation of section 702 involves the term "employment." Does this term encompass more than the decision to hire, and if so, what aspects of "employment" sliould be included? The resolution of tliese issues turns on a determination of how far the exemption can be extended to accommodate the free exercise riglit of religious organizations witliout violating either the Lemon establisliment clause test or the riglits of individuals to freely exercise their own religious beliefs without discrimination.

\section{SEction 702 AND the NATURE OF THE Religious ORGANIZATION'S ACTIVITY}

\section{A. Religious Preferences in Nonprofit Secular Activities of Religious Organizations}

Since section 702 was amended in 1972 to allow religious organizations to exercise preferences in all of their activities, one source of contention has been whether the exemption can constitutionally apply to the secular, nonreligious, or commercial activities of religious institutions. Ideally, the exemption should cover only the religious activities of religious organizations. The justification for the exemption's infringement on individual free exercise is that the free exercise clause requires that religious organizations be permitted to further their religious mission by prescribing the terms of employment for those who will carry out that mission. ${ }^{44}$ The free exercise clause does not clearly warrant this imposition on individual free exercise rights when the activity performed by the organization is not religious in nature. When the exemption does not advance the free exercise right of religious organizations, the balance of competing free exercise rights reflected in section 702 loses validity and the infringement on individual rights is not justifiable. ${ }^{45}$ Further, to ex-

43. Corporation of Presiding Bishop v. Amos, 483 U.S. 327, 339 (1987).

44. See id. at $342-43$ (Brennan, J., concurring in judgment).

45. Id. 
tend section 702 to a small group of secular activities-only those operated by religious institutions-constitutes governmental favoritism toward religion. 46 Such favoritism would violate the second part of the Lemon test, ${ }^{47}$ since allowing religious discrimination in secular activities goes beyond the accommodation of religion. The application of section 702 to nonreligious activities also could permit religious organizations improperly to extend their influence into the secular world. ${ }^{48}$

This analysis seems to lead to the conclusion that Section 702 should extend only to religious activities. However, any exemption that seeks to distinguish between religious and secular activities substitutes the judgment of the government for that of the religious organization as to whether the activity in question is religious or secular. ${ }^{49}$ Although an entity and its activities may appear to be nonrehgious to the government, the leaders of the religious organization may believe that such activities are vital to the church's mission..$^{50}$ For government to reserve the final say as to what is religious and what is secular entangles the government in religion and chills the organization's free exercise of religion..$^{51}$

The concerns associated with extending the exemption to the nonreligious activities of religious organizations, which resulted from the amendment of section 702, first surfaced in King's Garden, Inc. v. FCC. ${ }^{52}$ In that case, the FCC found that King's Garden, an interdenominational radio station, had discriminated in its employment decisions-decisions which involved some positions unrelated to religious broadcasts. The plaintiffs in King's Garden invoked the section 702 exemption and refused to comply with the FCC's request to submit a statement of future hiring practices. In dicta, the court stated that the 1972 exemption was

46. See, e.g., Mueller v. Allen, 463 U.S. 388, 397 (1983) (whether the provision extends benefits to a broad group is an important factor in determining secular effect under establishment clause inquiry); Committee for Pub. Educ. v. Nyquist, 413 U.S. 756, 794 (1973) (same).

47. Lemon v. Kurtzman, 403 U.S. 602, 612 (1971). For further discussion of this test, see supra notes 18-20 and accompanying text.

48. Corporation of Presiding Bishop v. Amos, 483 U.S. 327, 343 (Brennan, J., concurring in judgment); see also Amos v. Corp. of Presiding Bishop, 594 F. Supp. 791, 825 (D. Utah 1984) [Amos $I$ ]; King's Garden, Inc. v. FCC, 498 F.2d 51, 55 (D.C. Cir.), cert. denied, 419 U.S. 996 (1974).

49. Amos, 483 U.S. at 343 (Brennan, J., concurring in judgment).

50. One example of this difference in perceptions might be a health food company organization, operated by the church as a method of carrying out its health message. A church-operated gymnasium also might be viewed by the church as a vital part of its health message. For a further discussion of Amos, see infra notes 68-84 and accompanying text.

51. Amos, 383 U.S. at 343 (Brennan, J., concurring in judgment). This entanglement differs from that which occurs when the government determines what "religious" organizations can be taxed. In the taxation context, the government's decision has only economic consequences, while in the employment area, the government's characterization determines whether the religious organization can have a position it deems vital to the fulfilling of its religious mission filled by a person dedicated to that mission.

52. 498 F.2d 51, 53-54 (D.C. Cir.), cert. denied, 419 U.S. 996 (1974). 
of doubtful constitutionality because it covered all activities of any religious organization. The court believed that the free exercise rights of the employee outweighed those of the religious organization. A preference that extended to all activities, religious or otherwise, broadened the exemption beyond what was necessary for such organizations to freely exercise their beliefs. ${ }^{53}$ Further, the court stated that the amended version of section 702 violated the establishment clause by "invit[ing] religious groups, and them alone, to impress a test of faith on job categories, and indeed whole enterprises, having nothing to do with the exercise of religion." 54 The court saw the exemption as granting a special preference for religious organizations and showing favoritism by the government toward religion. ${ }^{55}$

In contrast to the dicta in King's Garden, a district court upheld the constitutionality of section 702 in Larsen v. Kirkham. ${ }^{56}$ The plaintiff in Larsen contended that section 702 conflicted with the establishment clause by permitting religious organizations to practice religious discrimination in connection with activities other than those of a religious nature-in this case the teaching of secular subjects. The court in Larsen, although confining its holding to the religious school exemption in Title VII's section 703(e), ${ }^{57}$ found no merit in the plaintiff's claim that a religious employer must reasonably accommodate the religious beliefs of its employees when such beliefs are not a "significant factor in the particular subjects being taught." 58

The court in Feldstein v. Christian Science Monitor ${ }^{59}$ also expressed concerns over the validity of section 702 . In Feldstein, the plaintiff alleged that the Christian Science Monitor had unfairly discriminated against him when it refused to hire him because he was not a Christian Scientist. The district court found that the close relationship between the Monitor and the Christian Science Church indicated that all employees

53. Id. at 56.

54. Id. at 55 .

55. Id. at 57.

56. 499 F. Supp. 960, 961 (D. Utah 1980) (plaintiff's teaching contract not renewed because school felt she was "insufficiently involved in ecclesiastical activities to justify her retention as a teacher at a church school"), aff'd without opinion, 32 Exec. Disclosure Guide (CCH) 133,827 (10th Cir. 1982), cert. denied, 464 U.S. 849 (1983).

57. 42 U.S.C. $\$ 2000 \mathrm{e}-2(\mathrm{e})(2)$ (1988) (for the language of this exemption see infra text accompanying notc 174).

58. Larsen, 499 F. Supp. at 966 (quoting Plaintiff's post-trial memorandum at 29).

59. 555 F. Supp. $974,975-76$ (D. Mass. 1983). Plaintiff alleged that he was not given full consideration for a position as a reporter for the defendant because he was not a Christian Scientist. The basis of Feldstein's claim was that the Monitor is an impartial, secular newspaper and thus not protected by an exemption for religious activities. Id. at 977 . He also asserted that an exemption under section 702 for all of the activities of a religious organization would be unconstitutional. Id. at 975. 
at the Monitor were involved in a religious activity. ${ }^{60}$ Thus, the court did not need to rely on that portion of section 702 that arguably applied to the secular activities of religious organizations. ${ }^{61}$ The court stated in dicta, however, that if the secular part of section 702 were involved, the court "would have grave doubts as to its ability to pass constitutional muster under the Establishment Clause of the First Amendment."62 The concerns of the Feldstein court centered on the unfair preference religious organizations would receive in comparison to secular, private-sector enterprises when conducting activities wholly secular in nature. ${ }^{63}$ The court stated that such a preference clearly conflicted with the commands of the first amendment. ${ }^{64}$ Presumably, this preference would violate the Lemon test's prohibition against governmental advancement of religion. ${ }^{65}$

The debate over the constitutionality of section 702 was clarified in 1987. In Amos $I$, the federal district court ruled that section 702's application to nonreligious activities unfairly singled out religious entities for a benefit by granting them "an exclusive authorization to engage in conduct which can directly and immediately advance religious tenets and practices." 66 Thus, the lower court declared the statute unconstitutional

60. Id. at 978 .

61. Id.

62. Id.

63. Id. at $978-79$.

64. Id. at 979 (citing Committee for Pub. Educ. v. Nyquist, 413 U.S. 756, 771 (1973), which noted that "a law may be one 'respecting an establishment of religion' even though. .. it does not aid one religion more than another but merely benefits all religions alike." (citation omitted)).

65. Lemon v. Kurtzman, 403 U.S. 602,612 (1971). For a further discussion of this requirement, see supra notes $15-17$ and accompanying text.

66. 594 F. Supp. 791,825 (D. Utah 1984). This case involved a challenge to alleged employment discrimination by three organizations: Beehive Clothing Mills, a nonprofit enterprise which manufactured and distributed clothing and temple garments; the Deseret Gymnasium, a gym open to the public; and Deseret Industries, which ran thrift stores that refurbished goods, sold clothing to the public, and provided jobs to those who could not find work. All were operated by a corporation owned by the Church of Jesus Christ of Latter-day Saints (the Mormons).

Because the court in Amos $I$ held section 702 to be unconstitutional as applied to the secular activities of religious organizations, the outcome in that case turned on whether the activities carried on there were secular or religious in nature. In making this determination, the court applied a threepronged test. Id. at 799 . This first prong took into consideration the nexus between the activity in question and the religious organization, paying particular attention to financial matters, management, and day-to-day operations. The seeond prong examined the relationship between the primary function of the activity and matters of church administration or church beliefs or rituals. If the first two prongs showed substantial relationships, then the court would have found the activity to be religious without proceeding to the third step of the test. Since the relationships in this case were tenuous, the court was forced to look to the third prong of its test, the relationship between the employee's activities and matters of church administration, tenets, or rituals. If this examination revealed a close relationship, then the court would have declared the activity to be religious. However, the court held that this test was not met by Deseret Gymnasium and granted summary judg- 
insofar as it extended to secular activities. ${ }^{67}$ However, on direct appeal, the Supreme Court rejected this rationale. 68 The Court found that when applied to both religious and secular nonprofit activities of religious employers, section 702 permissibly alleviates governmental interference with the ability of religious organizations to define and carry out their religious mission, and thus does not violate the establishment clause. ${ }^{69}$

The Amos Court based its decision on an interpretation of the threepart test in Lemon. The first and third prongs of this test posed no problem to the exemption. ${ }^{70}$ The real point of contention, for both the Supreme Court and the lower court, centered on whether the amended section 702 met the second requirement of Lemon. That requirement suggests that a statute violates the establishment clause if the law in question has the primary effect of advancing or inhibiting the practice of any particular religion. ${ }^{71}$ Justice White, writing for the Court, stated that for a law to have such an effect, "it must be fair to say that the government itself has advanced religion through its own activities and influence."72 Since this was clearly not the situation in the case at hand, this prong was not implicated. The Court held that the government's action in enacting legislation which singles out religious organizations for special consideration in their conduct of secular activities did not constitute a per se violation of this prong of the Lemon test. ${ }^{73}$ Although the Court acknowledged that prior decisions could be read to support the finding of

ment for the plaintiff. Id. at 831. Because of a lack of sufficient facts, the court did not reach the complaints regarding Deseret Industries and Beehive Clothing.

Amos I was followed a year later by Amos v. Corporation of Presiding Bishop, 618 F. Supp. 1013 (D. Utah 1985) [Amos II], in which plaintiffs from Amos I filed a second amended complaint adding an additional named plaintiff and moved for summary judgment on the complaints concerning Deseret Industries and Beehive Clothing. The court granted summary judgment in favor of the defendant, the Corporation of Presiding Bishop, on the claim concerning Deseret Industries, holding that the first and second prongs of its test were satisfied due to the substantial relationship between the Mormon Church and the Industries and between the charitable function of the Industries and the beliefs of the Church. Id. at 1030. Summary judgment was not granted on the Beehive Clothing claim, however, as material facts remained in dispute. Id. at 1016.

67. Amos I, 594 F. Supp. at 825.

68. Amos, 483 U.S. at 327.

69. Id. at 339.

70. The court found the first prong of the Lemon test-the secular purpose test-to not be violated since the purpose of Congress in passing the amendments to the exemption was to minimize government's interference with religious decisions. Id. at 336. The third requirement of the Lemon test-that the law not impermissibly entangle church and state-was also not violated, since section 702 "effectuates a more complete separation of the two and avoids the kind of intrusive inquiry into religious belief that the District Court engaged in this case." Id. at 339. For a further discussion of the Lemon test requirements, see supra notes 11-19 and accompanying text.

71. Lemon v. Kurtzman, 403 U.S. 602, 612 (1971).

72. Amos, 483 U.S. at 337.

73. Id. at 338 . 
a constitutional violation on grounds of favoritism, ${ }^{74}$ it held that those decisions did not mandate a similar outcome in this case since the government only enacted section 702 to lift a burden on the exercise of religion. ${ }^{75}$ The Court found no reason why legislation properly aimed at lifting burdens on religious organizations also had to benefit secular entities. ${ }^{76}$

The majority in Amos did not fully consider whether section 702's infringement on the free exercise rights of employees is justified when the activity in question is secular. Rather, the Court addressed an equal protection argument-that giving less protection to employees of religious employers than to employees of secular employers offends equal protection requirements. ${ }^{77}$ Because the statute was neutral with respect to the benefits accorded various religions, the Court held that it was not subject to strict scrutiny. ${ }^{78}$ Section 702 easily passed the Court's inquiry into whether "Congress had chosen a rational classification to further a legitimate end."79

Concurring in the judgment, Justice Brennan, joined by Justice Marshall, perceived greater difficulty for the exemption with regard to the second requirement of the Lemon test. He expressed concern that a categorical exemption for both religious and secular activities would extend a preference to religious organizations. ${ }^{80} \mathrm{He}$ also recognized that extending the exemption to cover secular activities caused an unnecessary infringement on individual free exercise rights. ${ }^{81}$ However, Justice Brennan believed that the exemption was preferable to excessive governmental entanglement in religious affairs. If the goverument attempted to distinguish between religious and secular activities, then the free exercise rights of religious institutions would be chilled. ${ }^{82}$ Justice Brennan also suggested that a categorical exemption could apply only to the nonprofit activities of such organizations. ${ }^{83}$ Justice O'Connor, concurring separately in the judgment, indicated that the Court's opinion left open the issue of whether the exemption could be applied constitutionally to forprofit activities. ${ }^{84}$ Thus, although the Supreme Court held that the ex-

74. See supra note 46 and accompanying text.

75. Amos, 483 U.S. at 338.

76. Id.

77. Id.

78. Id. at 339 .

79. Id.

80. Id. at 343 (Brennan, J., concurring in judgment).

81. Id. at $342-43$.

82. Id. at 343-44. For a further discussion of Justice Brennan's opinion, see infra notes 127-31 and accompanying text.

83. Id. at 345 n.6.

84. Id. at 349 (O'Connor, J., concurring in judgment). 
emption could apply to secular activities of religious organizations, it explicitly refrained from deciding whether for-profit activities would be covered.

\section{B. Section 702 and For-Profit Activities of Religious Organizations}

Whether the Amos rationale should extend to for-profit organizations presents an extremely sensitive first amendment problem. Commentators have made persuasive arguments for both the exclusion and the inclusion of for-profit activities. ${ }^{85}$ This question can be resolved only through a careful balancing of the free exercise clause and establishment clause.

1. For-Profits and the Establishment Clause. The Court determined in Amos that the application of the Lemon test is the appropriate method to determine when exemption statutes stray beyond the bounds of proper accommodation of religion and become "an unlawful fostering of religion." 86 Because the Court has adopted this test as the appropriate standard by which to examine the establishment clause ramifications of exemption statutes, it seems correct to analyze the distinction between nonprofit and for-profit organizations under this same kind of scrutiny.

Given the Court's interpretation in Amos that the first prong of the Lemon test invalidates only those laws enacted by Congress "with the intent of promoting a particular point of view in religious matters," 87 section 702 passed that prong of the test easily. ${ }^{88}$ The Court held that the legislative purpose of section 702 was simply to minimize governmental interference in the decisions of religious organizations. Because the intent of Congress in passing section 702 does not vary according to the activities to which it is applied, the Court's finding in the religious/secular context in Amos should also apply in the nonprofit/for-profit context at hand. Therefore, the first requirement of the Lemon test is satisfied. ${ }^{89}$

The second prong of Lemon - the prohibition of governmental advancement or inhibition of religion-presents greater difficulties. Since

85. See, e.g., Note, Permitting Religious Employers to Discriminate on the Basis of Religion: Application to For-Profit Activities, 1988 B.Y.U. L. REV. 221 [hereinafter Note, For-Profit Activities] (arguing that a categorical exemption should apply to for-profits); Note, Corporation of Presiding Bishop v. Amos: The Supreme Court and Religious Diserimination by Religious Educational Institutions, 3 Notre Dame J. L., Ethics \& PUB. Pol'Y 629, $659-60$ (1988) [hereinafter Note, The Supreme Court] (contending that the exemption should under no circumstances apply to for-profits).

86. Amos, 483 U.S. at 334-35 (quoting Hobbie v. Unemployment Appeals Comm'n., 480 U.S. $136,145(1987))$.

87. Id. at 335 .

88. Id.

89. See Note, For-Profit Activities, supra note 85, at 231 ("[o]bviously, the purpose for which a statute was passed does not change just because it is applied in another context"). 
Amos involved a nonprofit activity, the Supreme Court did not need to reach the question of the constitutionality of section 702 as it applies to for-profit activities. Thus, the lower court's concern in Amos I-that upholding a categorical exemption would allow churches to venture impermissibly into profit-making enterprises ${ }^{90}$-was left unresolved by the Supreme Court.91

For-profit entities are distinct from nonprofit enterprises in that forprofits can distribute their profits for general use by the church, while nonprofit entities must utilize their earnings to finance the continued operation of the enterprise itself. ${ }^{92}$ In light of this distinction, it is not surprising that most nonprofit entities controlled by church organizations do not operate simply to generate revenue, but exist instead to fulfill the mission of the church by providing a service both to its members and to the community. ${ }^{93}$ Applying a categorical exemption to for-profits permits religious organizations to pursue activities that are unconnected to the mission of the church-activities aimed solely at generating profit. ${ }^{94}$ The government could view a categorical exemption as according a special privilege to religious-based firms-a privilege denied to identical firms operated by secular organizations. ${ }^{95}$ Both types of firms generate profits as their sole aim, and yet only secularly operated enterprises would be forced to accommodate the religious beliefs of employees and those seeking employment. Such a preference by the government surely would raise concerns under Justice Brennan's understanding of the second part of the Lemon test, ${ }^{96}$ and under the district courts' opinions in Amos $I^{97}$ and Feldstein. ${ }^{98}$ Despite these concerns, the majority in Amos

90. 594 F. Supp. 791, 825 (D. Utah 1984).

91. The majority in $A m o s$, however, did indicate that merely allowing religious organizations to advance their religion is not an establishment of religion by the government. See supra note 72 and accompanying text.

92. See Hansmann, The Role of Nonprofit Enterprises, 89 YALE L.J. 835, 838 (1980).

93. Id.

94. See Marshall \& Blomgren, Regulating Religious Organizations Under the Establishment Clause, 47 Oнiо ST. L.J. 293, 324 (1986).

95. Id.

96. Corporation of Presiding Bishop v. Amos, 483 U.S. 327, 343 (1987) (Brennan, J., concurring in judgment) (legislation giving religious organizations advantages in secular pursuits "goes beyond reasonable accommodation"); see supra notes $15-17$ and accompanying text.

97. Amos v. Corp. of Presiding Bishop, 594 F. Supp. 791, 820 (D. Utah 1984) ("proper inquiry is whether the law in question has the direct and immediate, or substantial, effect of advancing or inhibiting religion"); see supra note 66 and accompanying text.

98. Feldstein v. Christian Science Monitor, 555 F. Supp. 974, 979 (D. Mass. 1983) (Religious discrimination legislation must be structured "in a way that neither favors nor disfavors secular, private sector enterprises that may be conducted by religious organizations."); see supra note 59-64 and accompanying text. 
seemed to suggest that even in the for-profit context, section 702 properly alleviated the impact of a regulation that burdens religion.99

The third prong of the Lemon-test-that the law steer clear of excessive entanglement with religion-requires an examination of the nature of the institutions that are benefited, the nature of the aid provided and the relationship between the government and the religious organization. ${ }^{100}$ Only the third factor affects the analysis of an exemption of forprofit activities. Any exemption of for-profits, other than a categorical one, would require a case-by-case analysis of whether an activity is religious or secular. Only a full understanding of the fundamental beliefs of a religion, a complete examination of an organization's inner workings, and a comprehension of its connection to the church can provide a correct and proper judgment with regard to the religious nature of an activity. This kind of scrutimy by the governinent leads to a disturbing relationship between the government and the church, analogous to the kind of entanglement Justice Brennan saw as inevitable if the Court in Amos attempted to draw a distinction between secular and religious activities. ${ }^{101}$

Thus, extending the section 702 exemption to include for-profit activities creates a tension among the separate requirements of the estabhishment clause. The situation presents an apparent trade-off between the dangers of a categorical exemption that, at least under some interpretations, improperly gives special consideration to rehigious organizations even though an activity is unrelated to the mission of the church, and the dangers of a case-by-case application of the exemption that improperly entangles the government in determining what activities are necessary for rehigious organizations to carry out their inissions. Refusing to allow an exemption for any of a religious organization's for-profit activities would eliminate this trade-off and would prevent the government from improperly advancing religion or becoming entangled in religious affairs.

2. For-Profits and the Free Exercise Clause. Although disallowing an exemption for any of a religious organization's for-profit activities appears to be the best option under an establisliment clause analysis, it is an unacceptable alternative under the free exercise clause. Sucl an alternative wonld prevent wholly religious for-profit organizations from exer-

99. 483 U.S. at 338 (When "government acts with the proper purpose of lifting a regulation that burdens the exercise of rehion, we see no reason to require that the exemption come packaged with benefits to secular entities."); see supra note 75 and accompanying text.

100. 403 U.S. 602,615 (1971); see supra note 22 and accompanying text.

101. 483 U.S. at $343-44$ (Brennan, J., concurring in judgment); see supra note 82 and accompanying text. 
cising preferences both necessary to their self-definition and vital to the mission of a church. ${ }^{102}$

A case-by case approach to for-profits also presents problems under the free exercise clause. In his concurrence in Amos, Justice Brennan noted that failing to extend a categorical exemption to both rehigious and secular activities could chill the free exercise activity of rehgious organizations. ${ }^{103}$ In a case-by-case analysis, a court's determination of what is vital to the mission of a religion might differ from the judgment of church leaders. The possibility of different interpretations would give religious organizations an incentive to use a religious classification only for those activities about which there could be no dispute in order to avoid constant litigation. ${ }^{104}$ A less than categorical exemption thus could interfere with the exercise of a rehgious organization's behiefs, a factor that courts consider to determine whether a statute violates the frec exercise clause. ${ }^{105}$ The issue of whether to extend the exemption to include for-profit activities poses the same dangers.

A categorical exemption also raises free exercise concerns. Any exemption for religious organizations affects the free exercise rights of employees and potential einployees. ${ }^{106}$ A blanket exemption of for-profit enterprises operated by rehgious institutions, however, poses the danger of infringing upon personal religious beliefs in which no countervailing state interest exists in allowing rehigious orgamizations to freely practice their own rehigion. This concern presents another consideration in the free exercise inquiry. ${ }^{107} \mathrm{~A}$ case-by-case analysis, in contrast to a categorical approach, would restrict the exeinption to those for-profits that further the mission of a church. Such an analysis would ensure that the infringement upon personal free exercise rights would be justified by a countervailing imterest of the state.

102. Id. at 342 (Brennan, J., concurring in judgment). An example of the problems caused by such an interpretation would be a for-profit hospital run by a religious organization. Such a hospital might deem it necessary to the carrying out of its religious mission to staff its nursing positions with members of its religious affiliation. Disallowing the exemption in all for-profit activities would thus interfere with such a hospital's free exercise rights.

103. Id. at $343-44$.

104. Id.

105. See, e.g., EEOC v. Fremont Christian School, 781 F.2d 1362, 1367 (9th Cir. 1986); EEOC v. Pacific Press Publishing Ass'n, 676 F.2d 1272, 1279 (9th Cir. 1982); EEOC v. Mississippi College, 626 F.2d 477, 488 (5th Cir. 1980), cert. denied, 453 U.S. 912 (1981).

106. Fremont, 781 F.2d at 1367 ("magnitude of the statute's impact on the exercise of religious belief").

107. Id. (existence of "compelling state interest justifying the burden imposed upon the exercise of the religious belief"). 
3. Balancing the Requirements. Given the apparent tension between the free exercise clause and the establishment clause and the separate requirements within each clause, how should an exemption of a rehigious organization's for-profit ventures be assessed? Where should the balance between the requirements of these two clauses be struck? Although no solution completely reheves these tensions, a case-by-case apphication of the section 702 exemption to for-profits best balances these requirements.

The majority in Amos was correct when it stated that an exemption which extends special preferences to secular activities is not per se invahd. ${ }^{108}$ However, the court went awry in holding that section 702 merely removed "a regulation that burdens the exercise of religion."109 A regulation that prevents discrimination in wholly secular activities in no way burdens the exercise of religion. The organization does not exercise a religious right when it acts in that capacity. It instead engages in business completely unrelated to religion. Only as to religious activities would a provision that allows the exercise of religious preferences remove a regulation that burdens the free exercise of religion. This rationale supports the apphication of section 702 only to those secular enterprisesboth nonprofit and for-profit-that a religious organization can show are religious in nature and vital to the church's religious mission. Any further extension of the exemption would fail establishment clause scrutiny as it would violate the second part of the Lemon test's prohibition on statutes which unfairly advance religion.

A case-by-case approach provides a useful franiework under free exercise clause analysis as well. As has been shown, a categorical denial of the exemption to all for-profits would violate an organization's right to freely exercise its religion. However, a categorical exemption infringes on the free-exercise rights of employees. This infringement can be justified only when the state provides a compelling countervailing interest in promoting the free exercise of religious belief by the religious employer. When the activity of the employer is not religious in nature, the countervailmg interest is not present. Thus, free exercise concerns also indicate that the exemption should only be applied to those for-profit activities which are religious in nature.

However, this free exercise analysis does not indicate that a case-bycase inquiry should apply to all of a religious organization's secular activities, both nonprofit and for-profit. As with the religious/secular distinction in general, a case-by-case analysis of whether for-profit activities are

108. 483 U.S. 327,338 (1987).

109. Id. 
rehigious or secular presents the dangers of both excessive government entanglement in religion and the chilling of a religious organization's free exercise rights. In the nonprofit arena, these dangers outweigh the potential for establishment of religion problems. However, these dangers are of less concern with regard to for-profits. ${ }^{110}$ Questions that concern the religious nature of an activity and " $[t]$ he risk of chilling religious organizations [are] most likely to arise with respect to nonprofit activities,"111 since for-profit status alone casts doubt on whether the activity has religious content. ${ }^{112}$

Further, the occurrence of some clilling effects and government entanglement resulting from a case-by-case analysis of the religious nature of for-profits seems to present a fair trade-off. If the religious institution wishes to carry out its imission and at the same time make a profit, it is reasonable to require it to prove that these profit-seeking ventures relate to its religious mission. The second part of the free exercise test-which requires inquiry into whether there is a compelling state interest that justifies the burden on free exercise-is satisfied if compelling dangers are present. ${ }^{113}$ A categorical exemption would threaten the balance between the free exercise and the establishment clause by unfairly aiding religious orgamizations and unjustifiably infringing upon the free exercise rights of employees, which indicates the existence of compelling countervailing dangers. A case-by-case approach best responds to these dangers by balancing the requirements of the religion clauses. Thus, the third part of the free exercise test, which examines the extent to which the objectives of the statute are mipeded, also is not violated by such an approacl. An interpretation of section 702 that prevents the exemption from violating the establishinent clause and the free exercise clause cannot be said to be contrary to the objectives of Title VII.

The problem of how a religious organization's for-profit activities sliould be treated under section 702 is a perplexing one. The religion clauses defy a perfect balance. The best that can be hoped for is a rough, three-way balance-an accommodation of the prohibition against governmental establishment of religion while still permitting free exercise of religion by both individuals and religious institutions. Denying the ex-

110. Id. at 343-44 (Brennan, J., concurring in judgment).

111. Id. at 344. Justice Brennan went on to state that:

Nonprofit activities therefore are most likely to present cases in which characterization of the activity as religious or secular will be a close question. If there is a danger that a religious organization will be deterred from classifying as religious those activities it actually regards as religious, it is likely to be in this domain.

Id. at 345 .

112. Id. at 344.

113. EEOC v. Fremont Christian School, 781 F.2d 1362, 1367 (9th Cir. 1986); see supra note 92 and accompanying text. 
emption to all for-profit organizations serves the free exercise interests of employees, but does so at too great an expense to the free exercise rights of the religious entity. In contrast, a eategorical exemption of for-profit entities tips the balance toward establishing religion while simultaneously deereasing individual free exercise rights. However, a case-by-case approach poses the comparatively minimal dangers of slight governmental entanglement in religion and a decrease in the free exercise rights of religious organizations. Given the coinparative dangers, a case-by-case application of the exemption to those for-profits that can show that they are religious in nature best balances the requirements of the religion clauses.

\section{The EXtent of the EMPloyment Relationship COVERED BY SECTION 702}

Whether or not the section 702 exemption includes for-profit entities is not the only ambiguity left by the language of the exemption and court decisions interpreting it. It is also unclear in what aspects of the employment relationship religious organizations should be allowed to exercise the exemption. Restricting the exeinption to only hiring decisions would mean rehigious organizations could not discharge those whose religious behefs had changed. Excluding promotions from coverage by the exemption would mean that once a person not of the organization's religion was hired for a lower-level position, he or she could not be denied promotion to higher positions more integral to the carrying out of the organization's religious mission. These are the concerns addressed by the remainder of this Note.

\section{A. Defining "Employment" in Section 702}

Section 702 exempts religious organizations from the requirements of Title VII "with respect to the employment of individuals of a particular religion to perform work connected with the carrying on ... of its activities."114 Because the exeinption does not indicate which aspects of the employment relationship it includes, the extent of the provision's coverage turns on interpretation of the ternn "einployment."

Although the EEOC correctly maintains that the term "employment" should be given its coinmon dictionary meaning, ${ }^{115}$ the Commission has limited the scope of the term by finding that "the act of employing" is the only relevant definition. ${ }^{116}$ The EEOC concedes that

114. 42 U.S.C. $\$ 2000 \mathrm{e}-1$ (1988).

115. Religious Organization Exemption, EEOC Compliance Manual (CCH) $\Uparrow 2183$, at 2364, 2368.

116. Id. 
such a definition must necessarily include the decision to discharge as well as the decision to hire, but maintains that the term "employnient" could not cover "terms, conditions, and privileges of employment." 117

Dictionary definitions illustrate that the term "employment" can have a relatively broad meaning. Webster's Dictionary defines "employment" as:

[A]ctivity in which one engages and employs his time and energies ...; the act of employing someone or something or the state of being employed. ${ }^{118}$

Black's Law Dictionary defines it as:

Act of employing or state of being employed; that which engages or occupies; that which consumes time or attention; also an occupation, profession, trade, post or business. . . . Activity in which person engages or is employed; normally on a day-to-day basis. ${ }^{119}$

Although the above definitions include the act of employmg within the term "employnient," they also extend beyond this definition. The references to the "state of being employed," or the "activity in which person engages, normally on a day-to-day basis" include niost of the aspects of a person's service as an employee. Given these broad definitions, the EEOC account of eniploynient as the act of being hired amounts to a constricted interpretation of the term "eniployment."

Rather than make a blanket determination of what the definition of "eniployment" includes as the EEOC has done, courts should determine the reading of the term that best fits with both the legislative intent behind the exeniption and the requirements of the religion clauses of the first amendment.

There is no clearly stated legislative purpose behind the section 702 exeniption, either in its form as first enacted in 1964 or as amended in 1972. The EEOC's position that "compensation, terms, conditions, and privileges of eniployment" are not included in the exemption, however, derives from the premise that the legislative history of the original exemption and the amended exemption "unequivocally" support a very narrow exception fron Title VII for religious organizations. ${ }^{120}$ This simply is not the case. Although a narrow interpretation of the exenıption is not wrong - and is in fact supported by a fairly recent court decision ${ }^{121}$

117. Id.

118. Webster's Third INTERnational Dictionary of the ENGlish LaNguage, UNaBRIDGED 743 (1986).

119. Black's Law Dictionary 471 (5th ed. 1979).

120. See Religious Organization Exemption, EEOC Compliance Manual (CCH) if 2183, at 2366.

121. EEOC v. Fremont Christian School, 781 F.2d 1362, 1366 (9th Cir. 1986) ("Both the language and legislative history of Title VII ... indicate that the statute exempts religious organizations only to a narrow extent."). For a further discussion of this case, see infra notes 148-50 and accompanying text. 
it is not the only plausible interpretation of the legislative history. In advocating the inclusion of religious educational institutions in the exeinption, Senator Ervin - one of the 1972 amendinent's chief sponsorsstated that:

[T] he amendment would exempt religious corporations ... from the application of this act insofar as the right to employ people of any rehigion they see fit is concerned.... [T] political hands of Ceasar off of the imstitutions of God, where they have no place to be. 122

This statement provides soine indication that Congress intended section 702 to serve a broad purpose.

The language of Title VII also militates against a narrow reading of "employinent." In listing those practices prohibited by Title VII, section 703 inakes it "an unlawful einployinent practice for an einployer," 123 to refuse to hire, to discharge an individual, or to discriminate against an individual "with respect to his compensation, terms, conditions, or privileges of employment, because of such individual's . . race."124 It certainly would be odd for the drafters to use the term "einployment" in section 702 to refer to only hiring and firing, and then to use the saine term in section 703 to refer to a broader concept of the employer/einployee relationship.

The EEOC also has taken the position that the primary goal behind the creation and amendinent of section 702 was to allow religious organizations to exercise preferences only with respect to hiring decisions. ${ }^{125}$ This position is also unsupported by the legislative history. Some of the legislative history indicates that-in addition to acts of hiring-the exeinption also was intended to cover both proinotion and discharge decisions. During the debate over the amendinent of section 702 in 1972, Senator Ervin stated that the exemption should be anended to include religious educational institutions because their exclusion froin the 1964 exeinption did not sufficiently protect their "religious liberty froin the invasion of the civil authorities when it gave the civil authorities power to regulate whom religious institutions . . . can einploy, whoin they inust proinote, whoin they must retain in einployinent, and whoin they may fire."126 Senator Ervin's reinark only makes sense if it is understood to

122. 118 CONG. Rec. 4503 (1972). For a further discussion of the legislative history of section 702, see Note, The Supreme Court, supra note 85, at 631-36 (arguing that the legislative history of the amendments to section 702 supports the broadest possible interpretation of that seetion).

123. Title VII of the Civil Rights Act, 42 U.S.C. $\$ 2000 \mathrm{e}-2$ (a) (1988).

124. 42 U.S.C. \$ 2000e-2(a)(1) (1988).

125. See Religious Organization Exemption, EEOC Compliance Manual (CCH) $\uparrow 2183$, at 2366 . 68.

126. 118 CoNG. REC. 1979 (1972); see also id. at 946-49 (remarks of Senator Allen). 
mean that section 702 was already broad enough to permit religious groups to condition promotion, employment, and firing upon the necessities of their religious mission.

In his separate concurrence in Amos, Justice Brennan also interpreted the exemption to include more of the employment relationship than just the initial decision to hire. ${ }^{127}$ His opirion stated that "[a]n exeinption says that a person may be put to the choice of either conforming to certain rehigious tenets or losing a job opportunity, a promotion, or ... employment itself." 128

Justice Brennan gave his interpretation of the rationale for the exemption and then summarized what he felt the exemption should accomplish. He began by pointing out that religious organizations necessarily define themselves through the persons they select to carry out the church's mission. 129 Justice Brennan recognized the tension between the free exercise rights of the religious organization-which require allowing organizations to exercise rehigious preferences in employment decisionsand the free exercise rights of employees and prospective employeeswhich inevitably are compromised when they must choose between their religion and a job. ${ }^{130}$ However, Justice Brennan felt that an imposition on individual rights was justified because he "deem[ed] it vital that, if certain activities constitute part of a rehigious community's practice, then a religious organization should be able to require that only members of its community perform those activities."131 As will be shown, a definition of "employment" that automatically excludes all aspects of employment other than hiring decisions would not coincide with this rationale. The EEOC defimition therefore raises serious questions with regard to the meaning that should be given to the term "employment" and the aspects of employment that should be covered by the exemption.

127. 483 U.S. 327,340 (1987) (Brennan, J., concurring in judgment).

128. Id. One might conclude from the fact that Justice Brennan and Senator Ervin both used the terms "employ" and "employment" independently of the term "promotion," that only the act of hiring should be included in section 702. However, neither Justice Brennan nor Senator Ervin was using the statutory definition of employment. Instead, they seemed to utilize an expansive conception of the term "employment" to interpret the statutory definition.

129. Id. at 341-43. In his opinion, Justice Brennan quoted a law review article that argued that religious organizations must have autonomy in structuring their internal affairs, so that they can "select their own leaders, define their own doctrines, resolve their own disputes, and run their own institutions. Religion includes important communal elements for most believers. They exercise their religion through religious organizations, and these organizations must be protected by the [Free Exercise] [C]lause." Id. at 341 (quoting Laycock, supra note 28, at 1389).

130. Amos, 483 U.S. at 342-43. However, Justice Brennan also stated that because religious organizations provide individuals with a community which fosters their values, respecting the church's right to define itself often furthers individual's free exercise rights as well. Id. at $\mathbf{3 4 2}$.

131. Id. at 342-43. 


\section{B. Section 702 and Hiring and Discharge Decisions}

The section 702 exemption clearly applies to decisions that involve hiring. ${ }^{132}$ Sucl decisions would be covered even under the most restrictive definition of "employment" i.e., "the act of employing."133 Inclusion of hiring decisions in the exemption also is necessary both to fulfill the purposes of the drafters of section 702 and its amendment and to allow the church the ability to determme who will carry out its mission. ${ }^{134}$

In addition, the exemption applies to the discharge of employees. Even the EEOC concedes that if the exemption did not apply to discharge, Congress' purpose would be frustrated since an employer would be unable to fire an employee whose religious beliefs clianged. 135 This right to exercise preferences in discliarge decisions also extends to situations where the religious organization originally lired a person not of the religion practiced by the organization and then discharged that person in order to hire a co-religiomist. ${ }^{136}$ Although the equities in favor of such an action may not appear as strong as the situation in which the religious beliefs of the employee cliange, the organization should still be exempt, since circumstances may arise which necessitate a co-religionist for that position. Alternatively, the organization may have reassessed the position and determined that a co-religionist is necessary to fill it adequately. Even if the person was discharged only because a co-religionist was not available when the non-member was lired and lias become available, the orgamzation slould still have the riglit to exercise the preference. Prior unavailability does not clrange the fact that the position is one the religious organization has deemed that a co-religionist could best fill. Under Justice Brennan's contention that the free exercise clause requires that religious organizations be allowed to choose those whom will carry out its religious mission, this is a decision that the organization must rightfully be allowed to make in order to avoid interference with its selfdefinition. ${ }^{137}$

132. The Equal Employment Opportunity Commission summarized the government's position with regard to these kinds of decisions by stating that "[i]n enabling a religious organization to lawfully exercise a preference based on religion at least with regard to hiring decisions, Congress's intent was to allow such an organization to create and maintain a work force composed of individuals of compatible religious behef." Commission Decision No. 83-6, EEOC Decisions (CCH) \ 6835 (1983).

133. See supra text accompanying notes 115-16.

134. See supra notes $125-29$ and accompanying text.

135. Commission Decision, No. 83-6 EEOC Decisions (CCH) ๆ 6835 (1983).

136. A co-religionist is a person belonging to the same religion as that with which the organization is affiliated.

137. See supra notes $129-31$ and accompanying text. 
In Larsen v. Kirkham, the district court held that the right to discrimmate in discharge decisions imcluded the right to fire employees who are church members, but who do not meet the standards of church participation. ${ }^{138}$ This position was supported by the Supreme Court's decision in Amos. 139 In Amos, the Court held that the exemption for religious organizations apphied to a church-operated gymnasium that discharged an employee beeause he failed to qualify for a temple recommendation, a certificate of eligibility to attend the temples of the Mormon Church. 140 These holdings remain consistent with the basic rationale for allowing preferences in hiring and discharge decisions.

\section{Section 702 and Compensation, Terms, Conditions, and Privileges of Employment}

As a result of its narrow interpretation of seetion $702,{ }^{141}$ the EEOC has taken the position that the exemption does not extend to "compensation, terms, conditions, and privileges of employment."142 To date, no

138. 499 F. Supp. 960,966 (D. Utah 1980), aff'd without opinion, 32 Exec. Disclosure Guide (CCH) I 33,287 (10th Cir. 1982), cert. denied, 464 U.S. 849 (1983). For a discussion of the facts surrounding Larsen, see supra note 56 and acconpanying text. In its holding the court stated that "it is inconceivable that the exemptions would purport to free rehigious schools to employ those who best promote their religious mission, yet shackle them to a legislative determination that all noininal members are equally suited to the task." Id. The court concluded by adding that the "[p]laintiff fails to detail the constitutional nuances which permit a religious organization to hire its own members to teach, but prohibit it from refusing to retain nominal members who are perceived as not in conformity with the currently expressed ideals of religious practice. This court can't fill that void." Id. at 967.

139. 483 U.S. 327,337 (1987).

140. Id.

141. See Religious Organization Exemption, EEOC Comphance Manual (CCH) I 2183, at 2364, 2368 (stating that the remedial purpose of the statute granting the exemption would be frustrated if the exemption afforded religious organizations was broadly construed). The EEOC supported this proposition by citing the opinion of the court in EEOC v. Fremont Christian School, in which a district court stated that "[b]oth the language and legislative history of Title VII ... indicate that the statute exempts religious institutions only to a narrow extent." 781 F.2d 1362, 1366 (9th Cir. 1986). For a further discussion of the proper interpretation of the exemption, see infra notes 125-30 and accompanying text.

142. Religious Organization Exemption, EEOC Comphance Manual (CCH) If 2183, at 2364. The Coinmission summarized its position by stating that "[t]his policy statement reflects the Commission's position that religious organizations and religious educational institutions are not exeinpt from liability under Title VII for discriminating in compensation, terms, conditions, or privileges of employment on the basis of religion." After explaining that it felt the exemption applied to hiring and discharge, the Commission went on to explain that:

The reasoning in this Commission Dexision cannot logically be extended to include other terms and conditions in the word "employment." No express or implied intent of Congress would be frustrated if compensation, terms, conditions, and privileges of employment were not included in the exception. To the contrary, it would frustrate the intent of Congress to end discrimination in all aspects of the einployment relationship without furthering the Congressional purpose of the exemption, to allow religious organizations to staff their institutions with individuals of compatible beliefs. In other words, once an organization has 
court has dealt explicitly with the issue of whether the exemption includes terms, conditions, and privileges of employment. Only one court has even remotely considered the issue. Within the sex discrimination context and im dicta, the Ninth Circuit rejected the argument that the exemption created by section 702 extends beyond hiring decisions and encompasses all other einployment practices. ${ }^{143}$ The court failed, however, to specify what "employment practices" included, simply concluding that rehgious organizations are exempt from the statute "only to a narrow extent." 144

There are no clear statements by the EEOC that indicate what it considers "terms, conditions, and privileges of employinent." Given the all-inclusive nature of the phrase and the EEOC's narrow construction of the exemption, it seeins likely that the Coinnission would interpret section 702 to exclude all aspects of the employment relationship other than hiring and discharge decisions. This interpretation would be both unfortunate and incorrect. The motivations behind a religious organization's exercise of preferences in the varying areas of the employment relationship are not necessarily the same. Further, the constraints of the establishment clause and the balance between the free exercise rights of the religious organization and the free exercise rights of the einployee also differ with the various aspects of employment. The exemption should not be categorically limited. Instead, the exemption should be analyzed through the case-by-case examination of potential terms, conditions, and privileges of employinent, in light of both the purpose behind section 702 and the requirements of the first amendinent's religion clauses. The renainder of this Note applies such an analysis to three areas of the employinent relationship that probably would be considered terms, conditions, or privileges, and thus excluded from section 702 by the EEOC: insurance and like benefits; compensation; and the opportunity for promotion.

1. Section 702 and Insurance and Like Benefits. Other than compensation, the only example of a non-exempt term, condition, or privilege of einployment provided by the EEOC appears in its Notice on the religious organization exemption. ${ }^{145}$ This Notice describes a hypothetical

chosen not to exercise its preference and has hired people with other beliefs, no Congressional purpose would be served by allowing the organization to discriminate as to terms and conditions.

Id. at 2366.

143. Fremont, 781 F.2d at $1365-66$ (defendant sought to apply the exemption to a health insurance program).

144. Id. at 1366.

145. Religious Organization Exemption, EEOC Compliance Manual (CCH) $\uparrow 2183$, at 2364. 
religious society that hires only employees of its own religion unless it cannot fill all of the positions with co-religionists. ${ }^{146}$ The society provides a life insurance policy only to those employees who are co-religionists. In the Notice, the EEOC takes the position that an employer ineeting this description would be liable for religious discrimination and would be required to pay premiums for all employees who had not benefited from past payınents due to their religious behefs. ${ }^{147}$

The Ninth Circuit's loolding in EEOC v. Fremont Christian School, ${ }^{148}$ appears to support the EEOC's position. Fremont concerned a cliurcli-owned and operated private school that provided liealtli insurance to its employees as a fringe benefit. However, this benefit was available only to heads of louseholds, described by the school as a single person or married man. This definition stemmed from the school's belief that in a marriage, only the husband can be the liead of the houseliold, regardless of his salary in relation to that of his wife. Altlrough the court's statutory holding was limited to a finding that the section 702 exemption does not cover gender-based preferences, ${ }^{149}$ the opinion indicated that the court would not have extended the exemption to include preferences in employnient benefits suclı as healtli insurance plans, regardless of whetler the discrimination was based on religion or gender. ${ }^{150}$

A religious organization miglt attempt to rationalize a preference with regard to insurance by explaining that its organization provides insurance tlirougl a corporation run by a worldwide cliurcli and funded by the tithe of cliurch members. Thus, the organization would argue that only those subsidizing the plan slould be allowed to participate. Denying the organization an exemption in this situation makes such a plan economically illogical since nonmember employees would reap the benefits of a plan in which they had not contributed.

Preferences in employer-provided insurance and similar benefits, lowever, do not constitute an integral part of a religious organization's need to define itself and its mission. If denied suclı a preference, the

146. Id.

147. Id.

148. 781 F.2d at $1365-66$.

149. Id. at 1366 .

150. In holding that this employment practice was not covered by the exemption, the court stated that:

Fremont Christian argues that the exemption created by $\S 702$ of Title VII ... for religious institutions extends beyond hiring practices and encompasses all other employment practices (e.g., the health insurance compensation program). Both the language and legislative history of Title VII, however, indicate that the statute exempts religious institutions only to a narrow extent.

Id. at $1365-66$. 
organization still would be free to choose whomever it wished to carry out its mission. If the church did choose to hire a nonmember, then it would be forced to provide him or her with the same benefits that coreligionists received. Once the religious organization hires non-church members, the church does not enhance its ability to define itself and its mission by discriminating on the basis of rehion in the material benefits that it provides to employees of equal rank. To obtain the same benefits as their co-workers, nonreligionists would be forced to sacrifice their own rehigious behiefs. In such a situation, no compelling interest-such as the self-definition of a religious organization-justifies the burden imposed on the individual's religious freedom. Further, balancing these competing free exercise clause requirements in favor of the employee would not impede the objective of the exeinption ${ }^{151}$-reinoving the hand of government froin rehigion so that rehgious organizations may define their mission by choosing those who will carry it out. ${ }^{152}$

2. Compensation. An employee's rate of coinpensation is one aspect of the employment relationship that clearly seems to be a "term" of employment. Thus, under the EEOC's definition of "employment," preferences in coinpensation would not be covered by the exeinption. Indeed, the EEOC has explicitly stated that compensation is excluded from the exeinption. ${ }^{153}$ A broader interpretation of "einployment," however, could easily cover compensation preferences. As with employer-provided insurance, courts should undertake a more rigorous analysis of whether the exemption should cover compensation preferences. Specifically, courts ought to examine the rationale for the exemption and determine whether the benefits that a coinpensation preference yields outweigh the infringenent on individual rights.

A religious employer might decide that co-religionists should be compensated at a higher rate than those who perform the same duties but who are not of the organization's faith. One potential rationale for such a preference would be the belief that co-religionists will be more dedicated in their work because of their coinmitment to the overall mission of the church, and, thus, would be of greater value to the organization than nonmembers. Although such a rationale might appear valid at first, on closer examination it is clear that the real inotivating factor behind this preference, like that advanced for preferences in insurance and like benefits, is an economic concern.

151. This is the third factor looked to in free exercise clause analysis. See supra note 25 and accompanying text.

152. See supra notes $125-31$ and accompanying text.

153. Religious Organization Exemption, EEOC Compliance Manual (CCH) ף 2183, at 2364. 
Excluding compensation preferences from the exemption does not prevent a religion from defining itself and its mission. Requiring a religious organization to compensate employees equally in no way prevents a rehion from choosing those whom it wishes to carry out its work. Although an organization may be forced to pay nonmembers more than it believes they are worth, it is still free to hire and staff as it wishes. Not only does the free exercise clause require that rehious organizations be given a right of self-definition, it also demands that consideration be given to the potential infringement on the free exercise rights of employees that occurs when employment or the terms of employment are conditioned on religious behefs. A statutory exemption that extends the right to exercise preferenees in compensation to rehgious organizations demies a nonmember employee the right to free exercise of religion. The employee cannot follow his or her rehigious behefs and still obtain equal pay for equal work. This infrimgement on imdividual rights is not outweighed by the purely economic concerns of the religious organization. Thus, although compensation is an aspeet of the employment relationship that could easily be mcluded within the term "employment," a careful balancing of these free exercise concerns demonstrates that it nevertheless should not be covered by section 702 .

Preferences in both compensation and imsurance and like-benefits have the potential to advance religion in violation of the establishinent clause. A statute that favors rehgious organizations violates the Lemon test prohibition aganist governmental advancement of religion. ${ }^{154}$ This danger is similar to the one that would occur if the exemption were extended categorically to all of a religious organization's for-profit activities, includimg those unrelated to the organization's religious mission. ${ }^{155}$ At least under the interpretation of Justice Brennan, ${ }^{156}$ if not that of the majority in $A m o s,{ }^{157}$ this prospect only can be justified by a counterbalancing free exercise concern that favors an extension of the exemption. In the case of both insurance and like-benefits, no such counterweight exists.

3. Promotions. The opportunity for promotion is an aspect of the employment relationship that potentially could be classified as a "privilege of employment." If the opportunity for promotion is a privilege of employment, then it too would be excluded from the section 702 exemp-

154. 403 U.S. $602,612-13$ (1971).

155. See supra notes 109-13 and accompanying text.

156. See supra notes $80-83$ and accompanying text.

157. See supra notes $68-79$ and accompanying text. 
tion under the EEOC's formulation. ${ }^{158}$ This exclusion would lead to an anomalous result. Religious organizations would be able to exercise a preference in choosing whom to hire, but once they hired a person not of the organization's religion, they effectively would have waived their riglit to reserve higher positions for co-religiomists. It is conceivable that an individual who does not sliare the organization's faith could become a managing member, a result tle exemption surely was designed to prevent. In addition, allowing religious organizations to exercise preferences in promotion only witl regard to those positions that the organization could prove require a co-religionist presents a scenario of government entanglement with religion that would force the government to make the same kinds of decisions that the drafters of section 702 sought to avoid. ${ }^{159}$

a. The opportunity for promotion-privilege of employment? Given past case looldings, it seems entirely possible, if not probable, that courts will classify the opportunity for promotion as a privilege of employment. A line of cases outside the religious discrimination context, two of which involved promotion to partnership in a law firm, would likely be influential in any potential decision.

In Lucido v. Cravath, Swaine \& Moore, ${ }^{160}$ the planitiff, a Catliolic with Italian ancestry, alleged that he was discriminated aganist with respeet to work assignments, training, rotation, outside work opportunities and promotions on account of his ancestry, religion or both. Because of a firm-wide policy that provided eacli associate with the opportunity for promotion witlim a rcasonable anıount of tinie, the District Court for the Southern District of New York held that the opportunity for promotion was a "term, condition or privilege of employment." Thus, the opportunity for promotion was subject to the requirements of Title VII. ${ }^{161}$ The court did not deeide whether Title VII applies to partners, since it ruled that the Act applies to the discrimination an employee suffers when lie or she is not selected for partner. ${ }^{162}$

158. See supra notes 116-17 and accompanying text.

159. See supra notes 121-22 and accompanying text.

160. 425 F. Supp. 123, 127 (S.D.N.Y. 1977).

161. Id. at 128.

162. The Lucido court stated that:

The opportunity to be promoted to a position not itself covered by Title VII does not mean that discrimination in that promotion eannot be protected by Title VII. In fact, the opportunity to be considered for a job not covered by Title VII can itself be "a term, condition or privilege of employinent"....

Id. 
Several years later, the Supreme Court was faced with a similar question in Hishon v. King \& Spalding. ${ }^{163}$ In that case, sexual discrimination, rather than racial or religious discrimination, was alleged as a basis for denying partnership in the law firm. The Court's ambiguous opinion could be construed as saying that once an employer chooses to provide the opportunity for proinotion to a class of employees, promotion becomes a privilege of employinent, and the firm cannot subsequently make promotion decisions in a discriminatory manner. ${ }^{164}$

The Seventh Circuit followed Hishon and expanded it beyond the partnership context in Mozee v. Jeffboat, Inc. ${ }^{165}$ Employees of Jeffboat charged the company with racial discrimination in promotions, compensation, and other terms and privileges of employment. The court held that the opportunity for proniotion was a privilege of employment at Jeffboat, and therefore, Title VII restrictions on discrimination applied. ${ }^{166}$

163. 467 U.S. 69 (1984).

164. Id. at 75-76. In its holding the Court stated that:

An employer may provide its employees with many benefits that it is under no obligation to furnish by any express or implied contract. Such a benefit, though not a contractual right of employment, may qualify as a "privileg[e]" of employment under Title VII. A benefit that is part and parcel of the employment relationship may not be doled out in a discriminatory fashion, even if the employer would be free under the employment contract simply not to provide the benefit at all. Those benefits that comprise the "mcidents of employment," or that form "an aspect of the relationship between the employer and employees," may not be afforded in a manner contrary to Title VII.

Id. at 75-76 (citations omitted).

However, this case was in large part influenced by the court's assumption that the defendant, King \& Spalding, made a promise to the plaintiff to consider her for partner. Indeed, one could read the opinions of both the majority and the concurrence to indicate that in the absence of this promise, the decisions of the lower court in favor of King \& Spalding may lave been affirmed. See Comment, Constitutional Law-Employment Discrimination vs. Freedom of Association-The Limits of Title VII Applicability to Partnership Admission in the Modern Law Firm-Hishon v. King \& Spalding, 3 N.Y.L. SCH. HUM. RTS. ANN. S07, 511 (1986). However, the court did indicate that the voluntarily instituted policy-considering all associates for partnership after employment with the firm for a specified period of time-might constitute a privilege or benefit of employment. Thus it would provide a cause of action independent of the contractual prourise. Hishon, 467 U.S. at 75. The applicability of Title VII to promotions absent a contractual promise to promote or an instituted scheme of promoting within a firm or company was left open by the court's decision. See Comment, supra, at 525.

165. 746 F.2d 365 (7th Cir. 1984).

166. The Mozee court stated that:

In Hishon, the Supreme Court decided that although the status of partner falls outside the domain of Title VII, advancement to partnership im a law firm was a "term, condition or privilege of employment for purposes of Title VII." Likewise, in this case, consideration for promotion to supervisory positions appears to be a privilege of employment and, as sucli, promotion decisions may not be made in a discriminatory manner.

Id. at 371 (quoting Hishon, 467 U.S. at 77). The court thus remanded to the district court for full consideration of the evidence of discrimination in promotions presented by the class of employees. Id. 
The full effect of Lucido, Hishon, and Mozee on the exercise of preferences in proinotions is not entirely clear. None of those courts explicitly stated how their holdings would apply where an employer made no express promise of future consideration for promotions or where the general company or firm policy does not include the opportunity for promotion. ${ }^{167}$ Because of the ambiguity in the Supreme Court's holding in Hishon, ${ }^{168}$ other courts conceivably could rule that-even in the absence of an express contractual promise or a general policy of considering all employees for promotion-the opportunity for prolnotion is a privilege of employment when an employer undertakes to promote persons with the same qualifications. Such a holding would prevent a religious employer from exercising a religious preference in promotions if taken in conjunction with the EEOC's narrow reading of "employment" in section $702 .{ }^{169}$

To avoid this result a rehigious organization could make the requirements for promotion clear to prospective employees. A contract clause could exphicitly state that certain positions are reserved for co-religionists and that promotion to those positions is not a privilege of employment for nonmembers. How effective that remedy would be is not clear, since courts could conceivably rely on Hishon's interpretation and regard the opportunity for promotion as always a privilege of employinent when an einployer undertakes to provide the opportunity to some inembers of a class of employees. If Hishon were interpreted in this fashion, and if the courts accepted the EEOC's position that all privileges of employment should be included within the general Title VII prohibition on discrimination in employment, ${ }^{170}$ then a contract provision would not perinit an einployer to avoid liability: The courts consistently lave held that an enployee cannot waive his Title VII rights. ${ }^{171}$

b. Preferences in promotions and religious organizations. Court deeisions over the past few years have not clarified the question of whether the section 702 exeinption should include promotions. One re-

167. The court in Hishon seened to assume that all law firms have such a policy. See Comment, supra note 164, at 525 .

168. See supra note 165.

169. See supra notes $115-16$ and accompanying text.

170. 42 U.S.C. § $2000 \mathrm{e}-2$ (1988).

171. See Alexander v. Gardner-Denver Co., 415 U.S. 36 (1974) (court held that the strictures of Title VII are absolute and can form no part of the collective bargaining process); EEOC v. Townley Eng'g \& Mfg. Co., 859 F.2d 610 (9th Cir. 1988) (court held that thcre can be no waiver of Title VII rights through covenants in employinent contracts, thus rejecting Townley's contention that the employee had waived his rights to accommodation by signing a page of the Employee Handbook which committed him to complying with Townley's policy of mandatory attendance at weekly devotional services), cert. denied, 109 S. Ct. 1527 (1989). 
cent case, Pime v. Loyola University of Chicago, 172 although not a section 702 exemption case, presented a similar issue. The plaintiff, a part-time teacher, alleged that his employer, Loyola Umiversity, violated section 703(a)(1) of Title VII ${ }^{173}$ when it refused to consider him for a full-time, tenure-track teaching position because he was Jewish. The Umiversity chose to award the positions to three Cathohics, all Jesuits. As an affirmative defense, Loyola asserted the statutory exemption to Title VII under section 703(e)(2). ${ }^{174}$ This provision allows rehgious schools, colleges, umiversities and other rehgious educational institutions to hire employees of a particular rehigion if such imstitutions are "in whole, or in substantial part, owned, supported, controlled, or managed by a particular religion or by a particular rehgious corporation, association, or society."175 The District Court for the Northern District of Illinois, however, concluded that Loyola did not prove that it was in whole or im substantial part, supported, controlled or managed by the Society of Jesus. ${ }^{176}$ Therefore, the exemption was not available to Loyola.

The court, however, did hold that the hiring of Jesuit priests in this case was reasonably necessary to the operation of the Umiversity. ${ }^{177}$ Therefore, the court allowed the discrimination under section 703(e)(1), ${ }^{178}$ which grants an employer the right to exercise religious preferences when religion is a "bona fide occupational qualification reasonably necessary to the normal operation of that particular busimess or enterprise." ${ }^{179}$ The Seventh Circuit affirmed this holding on appeal. ${ }^{180}$

172. 585 F. Supp. 435 (1984), aff'd, 803 F.2d 351 (7th Cir. 1986).

173. Title VII of the Civil Rights Act of $1964, \S 703(a)(1), 42$ U.S.C. $\S 2000 \mathrm{e}-2(\mathrm{a})(1)(1988)$. This section provides that it is unlawful for an employer "to fail or refuse to hire or to discharge any individual, or otherwise to discriminatc against any individual with respect to his compensation, terms, conditions, or privileges of employment, because of such individual's race, color, religion, sex, or national origin."

174. 42 U.S.C. $\S 2000 \mathrm{e}-2(\mathrm{e})(1)$ (1988).

175. Id. In 1972, section 702 was amended to explicitly include educational institutions. Arguably, this change permits such institutions to apply an even broader exemption in exercising preferences. See Note, The Supreme Court, supra note 85, at 629. The usefulness of the section 703 exemption thus remains in question.

176. $585 \mathrm{~F}$. Supp. at $440-41$.

177. Id. at 443 .

178. Id.

179. 42 U.S.C. $\S 2000 \mathrm{e}-2(\mathrm{e})(1)$ (1988).

180. Pine v. Loyola Univ., 803 F.2d 351, 354 (7th Cir. 1986). For a fuller discussion of the court's decision in Pime, sec Comment, Pime v. Loyola University of Chicago: The Seventh Circuit Extends the BFOQ Defense, 14 J. C. AND U.L. 607 (1988). The Comment argues that in affirming the district court decision, the Seventh Circuit took an unduly broad view of the BFOQ exemption. "[T]he majority opinion implies that a religiously-affiliated college or university is prima facie guilty of religious discrimination when it lires a member of a religious order to the exclnsion of other applicants. Courts have traditionally avoided such decisions." Id. at 613. An alternative to the inajority's opinion is that expressed in the concurrence by Judge Posner. It is his position that the plaintif did not even establish a prima facie case of discrimination because the complaint failed to 
c. Developing a proper analysis for preferences in promotions. As in the case with coinpensation and benefits such as insurance, denying an employee the opportunity for promotion to positions which are reserved for co-rehigionists infringes on the free exercise rights of the employee. Unlike other areas of employment, however, the failure to allow the organization the right to exercise such a preference greatly interferes with the organization's right to free exercise. The need, identified by Justice Brennan in Amos, ${ }^{181}$ for a religious organization to define itself by deciding to staff certain activities only with those committed to the religious mission cannot properly be met if promotions are excluded from the section 702 exemption. An eniployment shortage may necessitate the hiring of nounembers for positions the organization feels such persons can fill adequately. Conversely, a rehigious organization could adopt a general policy that defines certain positions that do not require co-religionists. Such a determination surely would not deprive the organization of the right to reserve other positions for menibers of its rehion. The EEOC

prove the requirements of either disparate treatment or disparate impact. Pime, 803 F.2d at 356. In expressing its preference for the position of Judge Posner, the Comment concludes by stating:

Finally, Pime raises the danger that other schools like Loyola, religious in character but not religiously controlled as defined by 42 U.S.C. $\$ 2000 \mathrm{e}-2(\mathrm{e})(2)$, open theinselves up to suits by members of the faculty or outside applicants if the institution requires certain employees to be inembers of a particular religious order. Cutting off the plaintiff's case at the prima facie stage would avoid this situation.

Comment, supra, at 618-19.

A recent unreported case, Young v. Shawnee Mission Medical Center, No. 88-2321-S, slip op. at 2 (D. Kan. Oct. 21, 1988) (LEXIS, Genfed library, Courts file), concerned an individual employed by the defendant to work as a clerk/receptionist in its Nursery Services Department. Young claimed that she was demied promotions because she was not a member of the Seventh-day Adventist religion, which operated the Medical Center. The Medical Center sought to dismiss the claim based on the religious organization exemption of section 702 . In a ruling that granted the defendant's motion to dismiss, the District Court for Kansas lield that the Seventl1-day Adventist operated medical center fell within the exemption since the plaintiff was alleging religious discrimination-the very type of claim exempted by the statute. Id. at 4.

The persuasive value of this case is somewhat doubtful. The result can be attributed to the fact that the plaintiff did not raise the right issues. Young did not assert that section 702 covered only hiring and firing to the exclusion of promotion decisions and other terms, conditions, and privileges of employment. Rather, she attempted to show that through the acceptance of federal funds in the form of Medicare payments on belialf of some patients, the Medical Center relinquished the protection of section 702. The court found this argument wholly unpersuasive in light of Fike v. United Methodist Children's Home of Va., 709 F.2d 284 (4th Cir. 1983) (Circuit court affirmed district court's reasoning that purpose of such payments is to compensate the hospital for services rendered, not to provide general funding that the lospital inay allocate as it wishes; therefore, not sufficient to transform the vendor's action into that of the State), and Trageser v. Libbie Rehabilitation Center, 590 F.2d 87 (4th Cir. 1978) (private action to redress employment discrimination may not be maintained unless the primary objective of the funds is to provide employinent), cert. denied, 442 U.S. 947 (1979), both of which held that the receipt of Medicare payments did not qualify as federal assistance and was insufficient to revoke the statutory exemption.

181. Corporation of Presiding Bishop v. Amos, 483 U.S. 327, $341-43$ (1987) (Brennan, J., concurring in judgment); see supra notes 129-31 and aceompanying text. 
analysis, however, would preclude an organization from filling lower level positions with nonmembers, unless the organization could assure such employees the opportunity for promotion to higher-level positions. This dilemma would arise even if the organization beheves those positions require co-rehigionists.

The desire of rehgious organizations for an exemption that covers promotions has no basis in inaterialistic concerns or matters of efficiency. ${ }^{182}$ Rather, such a desire goes to the very heart of the organization's need to define both its mission and the means necessary to carry it out. This self-determination is vital to the organization's autonomy. Where the ability of a church to fulfill its religious purpose is at stake, an extension of the exemption is a reasonable and necessary accommodation of rehgion. Giving rehions the rights that are necessary to frecly exercise their behefs cannot be said to be an imipermissible governmental advancement of rehion. Indeed, such an interpretation comcides with both the interpretation of Justice Brennan ${ }^{183}$ and the interpretation of the majority in Amos. ${ }^{184}$ Further, the right of an organization to frecly exercise rehigious beliefs is a compelling state interest that justifies the burden plaeed on the frec exercise rights of a nonmember employce in line for promotion.

Failure to extend the exemption to proinotions would pose potential problems with the third part of the Lemon test, which limits government entanglement in religious affairs. ${ }^{185}$ With the section 702 exenuption removed by the EEOC's analysis, a rehigious organization would be forced to resort to section 703(e)(1) in order to exercise a preference in promotions. ${ }^{186}$ This provision requires that the organization show religion to be a "bona fide oceupational qualification" (BFOQ) for the position in question. This route was taken by the inajority in Pime v. Loyola University of Chicago. ${ }^{187}$ The BFOQ exception requires the rehious employer to show that filling a position with a church member is "reasonably necessary to the normal operation of that particular business or enterprise." 188 Such a determination forces the government to make a detailed examination of the rehious organization's structure. Thus, the government's determination would be substituted for the judgment of the

182. Such are the only types of rationales that might possibly be hypothesized for preferences in compensation and insurance and like benefits. See supra text accompanying notes 151-55.

183. Amos, 483 U.S. at $341-43$ (Brennan, J., concurring in judgment).

184. Id. at 337-38.

185. Lemon v. Kurtzman, 403 U.S. $602 ; 613$ (1971).

186. Title VII of the Civil Rights Act, § 703, 42 U.S.C. § 2000-2(e)(1) (1988).

187. 585 F. Supp. 435,443 (N.D. Ill. 1984), aff'd, 803 F.2d 351 (7th Cir. 1986); see supra notes 169.76 and accompanying text.

188. 42 U.S.C. $\S 2000 \mathrm{e}-2(\mathrm{e})(1)(1988)$. 
organization. This kind of analysis by the government would result in the same entanglement problems that would occur if the government attempted to determine whether an activity is truly religious in nature. ${ }^{189}$ Such scrutiny by the government would also chill the free exercise of rehigion by the organization since the organization would have an incentive to characterize rehgion as a "bona-fide occupational qualification" for only those positions that clearly qualify for the exemption. ${ }^{190}$

The entanglement and free exercise concerns associated with allowing preferences in promotions under the BFOQ exception does not mean a case-by-case analysis would similarly be problematic in determining whether for-profits are intertwined with the rehgious mission of the church. Part of the justification for using a case-by-case approach in the for-profit context is that the risk of chilling religious activity is low because most activities that are truly a part of the cliurcli's religious mission are nonprofit. It does not seem unfair to allow governinent to mquire into the nature of organizations that claim to carry out their cliurch's mission and make a profit at tlie same time. Nonprofit organizations and for-profits that have proven their rehgious nature, however, sliould not be subjected to government inquiry.

Even if no potential entanglement or clilling of free exercise would occur, forcing rehigious organizations to classify religion as a "bona-fide oceupational qualification" for certain positions is an unsatisfactory requirement for religious definition. As Pime makes clear, "the exemption based on bona-fide occupational qualifications was meant by Congress to be an extremely narrow exception to the general prolibition of employment discrimination on the basis of religion, sex, or national origin." 191 By contrast, Congress intended to create a special provision for religious organizations that would provide tliem witl a broad exemption, ${ }^{192}$ so

189. This is a determination the Suprene Court refused to make, thus rejecting a distinction under section 702 between religious and secular activities. Corporation of Presiding Bishop v. Amos, 483 U.S. 327 (1987) (holding section 702 to be constitutional as applied to the secular activities of religious organizations).

190. This is analogous to the incentive to characterize as religious only those activities over which there would hikely be no dispute, which Justice Brennan thought would result if the Court were to rule in Amos that the exemption apphed only to the religious activities of religious organizations. Id. at 343-44 (Brennan, J., concurring in judgment).

191. Pime, 585 F. Supp. at 441 . For a more complete discussion of Pime, see supra notes 172-78 and accompanying text.

192. See 118 CoNG. REc. 7567 (1972) (statenent of Rep. Erlenborn that educational institutions would be included in what was intended to be a broad exemption for religious organizations), reprinted in Subcomm. on Labor of the Senate Comm. on Labor and Public Welfare, Leg. ISLATIVE HistoRy OF THE EQUAL EMPLOYMENT OPPORTUNITY ACT OF 1972, 92d Cong., 2d Sess. 1249 [hereinafter LEGISLATIVE HISTORY]; see also statement of Senator Ervin, supra note 126 and accompanying text. 
that such organizations could exercise preferences in all positions. ${ }^{193} \mathrm{Re}-$ quiring religious organizations to use the much narrower BFOQ exemption for all positions other than those for which the einployee is initially hired greatly restricts the autonomy Congress originally intended to grant rehgious organizations under section 702.

\section{CONCLUSION}

The court decisions, legislative history, and agency rulings that deal with the right of religious organizations to exercise preferences on the basis of religion do not inake this an area remarkable for its clarity. Indeed, uncertainty is pervasive. However, a careful examination and consideration of the issues involved yields soine answers.

The rehigion clauses of the first amendment support the right of religious organizations to exercise religious preferences in all of their religious activities and in their nonprofit secular activities. This should mclude all for-profit enterprises that the organizations can demonstrate to be vital to the religious mission of the church.

Balancing the requirements of the religion clauses also is required to determine what aspects of the employinent relationship should be covered by section 702. Contrary to the position of the EEOC, a wholesale ruling that all terms, conditions, and privileges of employment are excluded does not constitute the kind of careful balancing necessary to fulfill constitutional requirements and to comply with the purpose of the exemption. Careful consideration inust be given to each area of the einployment relationship $\mathrm{m}$ order to determine the areas that should be covered. When such an analysis is undertaken, it becoines clear that extending section 702 to cover preferences in coinpensation and insurance and like-benefits satisfies neither the purpose of the exemption nor the constitutional provisions that both require and linit the exemption. However, this same approach clearly requires that the exemption cover the opportunity for promotion.

The sanctity of religion is too inportant to allow wholesale judginents to control where thoughtful analysis of constitutional principles leads to a result that is inore consonant with the intent of the drafters of the exemption and of the first amendment. The conclusions reached in this Note provide not only an alternative to the positions of the EEOC

193. See 118 CONG. REc. 4941 (1972) (statement of Sen. Williams), reprinted in LegisLATIVE History, supra note 192, at 1770. 
and previous court decisions, but also a position that is both constitutionally and historically sound.

Scott D. McClure 